\title{
EFEKTIFITAS MODAL KERJA DAN LIKUIDITAS SERTA DAMPAKNYA PADA KEBIJAKAN DIVIDEN PERUSAHAAN BERBASIS SYARIAH
}

\author{
Ahmad Rijal \\ ahmadrijal757@gmail.com \\ Salmah Said \\ Jurusan Manajemen, Fakultas Ekonomi dan Bisnis Islam, UIN Alauddin Makassar \\ salmahsaid@uin-alauddin.ac.id
}

Keywords:
Financial Performance,
Working Capital,
Liquidity, Dividend Policy,
Jakarta Islamic Index

Kata Kunci:

Kinerja Keuangan, Modal

Kerja, Likuiditas,

Kebijakan Dividen,

Jakarta Islamic Index

\section{ABSTRACT}

This article discusses to analyze the companies' financial performance i.e. the effect of working capital measured by Net Working Capital (NWC) on dividend policy as proxied by Dividend Payout Ratio (DPR), the influence of working capital on liquidity as measured by Current Ratio (CR), the influence of liquidity on dividend policy and the effect of working capital on dividend policy through liquidity. This study was conducted on companies registered consistently in the Jakarta Islamic Index (JII) in Indonesia Stock Exchange (BEI). This study uses path analysis to examine the effect of working capital on dividend policy with liquidity as an intervening variable. The results of this research showed that working capital had no significant effect on dividend policy. In other words, an increase in working capital cannot affect the dividend policy decisions taken by the company. In addition, working capital did not have a significant negative effect on liquidity. This study also found that liquidity had no significant relevancy on dividend policy so. Furthermore, liquidity was not able to mediate working capital on dividend policy, as working capital did not influence dividend policy though liquidity is one factor influencing dividend policy.

Artikel ini membahas tentang kinerja keuangan perusahaan yaitu pengaruh modal kerja yang diukur dengan Net Working Capital (NWC) terhadap kebijakan dividen yang diukur dengan Dividend Payout Ratio (DPR), pengaruh modal kerja terhadap likuiditas yang diukur dengan Current Ratio (CR), pengaruh likuiditas terhadap kebijakan dividen dan pengaruh modal kerja terhadap kebijakan dividen melalui likuidias. Objek dalam artikel ini pada perusahaan yang terdaftar secara konsisten dalam Jakarta Islamic Index (JII), di Bursa Efek Indonesia (BEI). Teknik yang digunakan adalah analisis jalur untuk menguji pengaruh modal kerja terhadap kebijakan dividen dengan likuiditas sebagai variabel internvening. Hasil yang diperoleh menunjukkan bahwa modal kerja tidak berpengaruh signifikan terhadap kebijakan dividen. Dengan kata lain, peningkatan modal kerja tidak dapat mempengaruhi keputusan kebijakan dividen yang diambil oleh perusahaan. Selain itu, modal kerja tidak berpengaruh negatif signifikan terhadap likuiditas. Dalam artikikel ini juga menemukan bahwa likuiditas tidak berpengaruh signifikan terhadap kebijakan dividen. Selanjutnya, likuiditas tidak mampu memediasi modal kerja terhadap kebijakan dividen, karena modal kerja tidak memengaruhi kebijakan dividen walaupun salah satu faktor berpengaruh terhadap kebijakan dividen adalah likuditas. 
Ahmad Rijal, dan Salmah Said. Efektifitas Modal Kerja dan Liquiditas...

\section{PENDAHULUAN}

Pasar modal adalah salah satu lembaga intermediary yang menghubungkan antara perusahaan yang membutuhkan dana dengan investor yang mencari keuntungan. Perusahaan memperoleh dana dengan menjual hak kepemilikan (saham) dan klaim utang (obligasi) perusahaan kepada masyarakat. Umumnya produk pasar modal adalah instrument investasi jangka panjang yang diterbitkan oleh pemerintah, public authorities, dan perusahaan swasta (Husnan, 2004).

Umumnya, kinerja pasar modal diukur dengan nilai indeks harga saham. Pasar modal di Indonesia dikenal dengan Bursa Efek Indonesia (BEI) memiliki 15 macam indeks saham, salah satunya adalah Jakarta Islamic Index (JII) yang terdiri dari 30 emiten. JII masuk dalam kriteria saham syariah dan memiliki kapitalisasi pasar yang besar dan likuiditas yang tinggi. JII diperbaharui setiap 6 bulan sekali, yang disesuaikan dengan periode penerbitan Daftar Efek Syariah (DES) oleh Otoritas Jasa Keuangan (OJK). Setelah dilakukan penyeleksian saham syariah oleh OJK, kemudian BEI melakukan proses seleksi lanjutan yang didasarkan kepada kinerja perdagangannya (IDX: 2015). Instrumen keuangan pasar modal terdiri dari saham dan obligasi. Investor memperoleh capital gain dan dividen (saham) dan fixed income (obligasi) (Kasmir, 2010). Di sisi lain, perusahaan memperoleh tambahan modal dari penerbitan saham dan obligasi.

Perusahaan mencurahkan perhatian yang lebih terhadap pengelolaan modal kerjanya agar lebih efisien, karena proporsi modal kerja adalah bagian yang cukup besar dari total aktiva. Modal kerja diperlukan secara kontinu untuk membiayai operasional perusahaan sehari-hari, dimana dana tersebut diharapkan dapat kembali lagi masuk dalam perusahaan melalui hasil penjualan produksinya (Kasmir, 2010). Penjualan produksi meningkat karena didukung manajemen modal kerja yang baik. Selain itu, penyediaan modal kerja juga untuk memenuhi kebutuhan likuiditas perusahaan, artinya likuiditas suatu perusahaan sangat tergantung kepada manajemen modal kerja. Salah satu nilai penting dari likuiditas perusahaan adalah ketersediaan dana pada saat dibutuhkan untuk membayar kewajibannya, terutama utang jangka pendek. Ketidakmampuan perusahaan dalam memenuhi kewajibannya akan memengaruhi aktivitas usahanya. Lebih lanjut, dalam manajemen modal kerja, sumber dan alokasi dana adalah hal penting terkait aktivitas usaha. Jadi, adanya manajemen modal kerja dan pengelolaan likuiditas yang baik dapat meningkatkan laba perusahaan, juga menyejahterakan para pemegang saham dengan pembagian dividen. Komponen modal kerja bersih yang berpengaruh langsung terhadap kesehatan likuiditas adalah asset dan kewajiban lancar (current assets dan current liabilities) yang diukur dengan Rasio Lancar (Current Ratio), dimana selisih keduanya merupakan modal kerja bersih (net working capital) (Muslich, 2003).

Pembagian dividen ditentukan dengan Dividend Payout Ratio (DPR) atau menjadi retained earnings untuk ekspansi usaha diputuskan Rapat Umum Pemegang Saham (RUPS). Perusahaan yang mempunyai laba yang besar membagi dividen kepada pemegang saham setiap tahun tergantung kebijakan yang ditetapkan suatu perusahaan. Salah satu faktor yang memengaruhi kebijakan dividen, adalah likuiditas perusahaan, yaitu posisi likuiditas/kas yang kuat memungkinkan pembayaran dividen yang tinggi (Riyanto, 2001; Binastuti, 2012).

Secara teori, terdapat hubungan negatif antara likuiditas dan profitabilitas, dimana tingkat likuiditas perusahaan yang tinggi akan menurunkan tingkat profitabilitas perusahaan menurun, sehingga dividen yang dibagikan menjadi rendah (Yulenda, et.al, 2017; Widnyana, 2015, meskipun terdapat penelitian yang menemukan bahwa likuiditas berhubungan positif dengan profitabilitas (Bisma, 2009). Demikian juga sebaliknya, ketika dividen yang dibagikan tinggi, hal itu menunjukkan tingkat profitabilitas perusahaan tinggi namun tingkat likuiditas perusahaan menurun (Yulenda, et.al, 2017; Widnyana, 2015). Secara empiris, kondisi ini digambarkan pada Tabel 1 berikut. 
AL-MASHRAFIYAH: Jurnal Ekonomi, Keuangan, dan Perbankan Syariah Volume 2, Nomor 2, Oktober 2018

Tabel 1. Kinerja Keuangan Perusahaan JII di BEI

\begin{tabular}{cccc}
\hline Tahun & $\begin{array}{c}\text { Kebijakan Dividen } \\
\text { (Dividend Payout Ratio) }\end{array}$ & $\begin{array}{c}\text { Likuiditas } \\
\text { (Current Ratio) }\end{array}$ & $\begin{array}{c}\text { Modal Kerja } \\
\text { (Net Working Capital) }\end{array}$ \\
\hline 2011 & $52,61 \%$ & $287,35 \%$ & Rp. 5.160 .877 .166 .667 \\
2012 & $55,72 \%$ & $256,3 \%$ & Rp. 5.992 .536 .750 .000 \\
2013 & $68,82 \%$ & $228,89 \%$ & Rp. 5.882 .443 .750 .000 \\
2014 & $52,245 \%$ & $202,72 \%$ & Rp. 6.401 .633 .750 .000 \\
\hline
\end{tabular}

Sumber: Data diolah dari website BEI (www.idx.co.id)

Tabel 1 menunjukkan fluktuasi Dividend Payout Ratio-DPR sebagai proksi dari kebijakan dividen perusahaan JII di BEI. Degnan kata lain, hal ini menunjukkan bahwa naik turunnya tingkat persentase laba yang dibagikan perusahaan kepada para investor (dividen) selama periode 2011-2014. Sedangkan Current Ratio pada Jakarta Islamic Index (JII) di atas 100\% dari tahun 2011 sampai tahun 2014, sehingga likuditas perusahaan JII tergolong baik. Adanya kemungkinan kebijakan dividen dipengaruhi oleh tingkat likuiditas ditunjukkan melalui trend negative dari rerata Current Ratio selama empat tahun. Rerata DPR perusahaan JII tahun 2014 sebesar 52,245\% yang merupakan nilai terendah selama empat tahun tersebut. dan juga diikuti dengan persentase terendah Current Ratio pada tahun 2014 sebesar 202,715\%. Hal ini membuktikan bahwa salah satu faktor yang memengaruhi kebijakan dividen adalah tingkat likuiditas (Riyanto, 2001).

Kebutuhan modal kerja perusahaan JII dengan proksi Net Working Capital (NWC) juga mengalami fluktuasi, sedangkan nilai Current Ratio mengalami penurunan selama periode tersebut. Salah satu faktor yang memengaruhi modal kerja adalah likuiditas Kasmir, 2010). Hal ini menunjukkan bahwa likuiditas dan modal kerja memiliki hubungan terbalik. Dengan kata lain, ketika nilai Current Ratio menurun, nilai NWC semakin meningkat.

Sebelumnya telah banyak yang meneliti tentang pengaruh modal kerja terhadap kebijakan dividen. Salah satunya adalah penelitian Oladipupo dan Ibadin yang menemukan modal kerja berhubungan negatif terhadap kebijakan dividen (Oladipupo dan Ibadin, 2013). Selain itu, penelitian tentang pengaruh likuiditas terhadap kebijakan dividen menunjukkan bahwa likuiditas berpengaruh positif terhadap kebijakan dividen (Afriani, et.al., 2013). Penelitian Supriadi dan Fazriani (2011) mengenai pengaruh modal kerja terhadap likuiditas menunjukkan bahwa pengaruh Current Ratio dipengaruhi secara positif signifikan oleh modal kerja. Terakhir, hasil penelitian likuiditas sebagai variabel intervening menunjukkan Working Capital Turnover (WCT) berpengaruh negatif namun tidak signifikan terhadap likuiditas (Andanarini dan Savitri, 2013).

\section{LANDASAN TEORI}

Dalam pandangan Islam, kegiatan investasi merupakan salah satu kegiatan muamalah, karena terkait interaksi dengan orang lain baik secara individu maupun secara kelompok, seperti perseroan, yayasan, dan negara (Afriani, et.al, 2013). Dalam kaidah fiqh, hukum asal kegiatan muamalah adalah mubah (boleh), kecuali yang jelas ada larangannya dalam Al-Qur'an dan Al-Hadis. Hal ini juga menjadi prinsip pasar modal syariah, yang melarang riba, maisir dan gharar (an-Nabhani, 1996; Jusmaliani, dkk, 2008; Saputra, 2012). Kriteria ini ditegaskan Allah dalam Al-Qur'an, QS. Al-Baqarah: 275. Allah mengetahui mana yang baik bagi hamba-Nya, maka Allah membolehkannya, sedangkan mana yang membahayakan hamba-Nya, maka dilarangnya (Departemen Agama, 2009). Melalui ayat ini, Allah menghalalkan jual beli, mengharamkan riba dan meninggalkan sisa riba (Shihab, 2002) . Riba dianggap sebagai eksploitasi terhadap sesama manusia karena ada kelebihan/tambahan harta yang diambil, dan ini merupakan bentuk kedzaliman terhadap orang lain (As-Sabitin, 2009; Shibab, 2002). 
Ahmad Rijal, dan Salmah Said. Efektifitas Modal Kerja dan Liquiditas...

Di lain pihak, jual beli adalah kegiatan yang didasarkan pada prinsip kerelaan antara perusahaan (penjual) dengan investor (pembeli), yang menghasilkan maslahat/manfaat bagi kedua pihak (Qosim, 2009). Di pasar modal syariah, prinsip syariah juga menjadi dasar dalam transaksinya, salah satunya larangan spekulasi (maysir) seperti ditegaskan dalam QS. AlMaidah:90 (Departemen Agama, 2009). Spekulasi terjadi jika investor hanya mencari laba dari perbedaan harga jual dan beli dalam transaksi jangka pendek, sehingga perusahaan tidak dapat memanfaatkan modal dari investor, bahkan hal ini juga dapat merugikan investor sendiri (Firdaus, 2005). Prinsip pasar modal syariah lainnya adalah larangan adanya unsur ketidakjelasan (gharar) dalam transaksi saham. Gharar dapat mengarah pada tindakan penipuan karena adanya ketidakjelasan dari sisi harga, kualitas, kuantitas, maupun eksistensinya (Zain, 2016; Jusmaliani, 2008; Saputra, 2012). Larangan Rasulullah SAW terkait jual beli yang mengandung gharar ini dikemukakan dalam hadis riwayat Abu Hurairah (dalam Kitab AlBuyu).

Kerjasama dalam bentuk syirkah amwal yang dapat diimplementasikan di pasar modal syariah adalah syirkah musahammah, yaitu penyertaan modal usaha yang dihitung dengan jumlah lembar saham yang ditransaksikan sehingga pemiliknya dapat berganti-ganti dengan mudah dan cepat. Dengan kata lain, pertanggungjawaban investor sesuai dengan jumlah saham yang dimiliki, yang berarti bahwa keuntungan (dividen) dan kerugian yang diterima sesuai dengan jumlah saham yang dimiliki (Muhammad, 2014). Dengan syirkah musahammah, perusahaan menmperoleh modal dari saham yang dijualnya dan investor memperoleh dividen dari saham yang dibelinya, sehingga tercipta kesejahteraan bagi kedua pihak. Hal ini sesuai dengan QS. Al-Maidah:2 (Ibnu Qayyim, 2010). Ayat tersebut menegaskan bahwa perbuatan baik yang didasari niat ikhlas akan menghasilkan kebaikan kepada individu dan masyarakat, seperti syirkah al-ta'awun) dalam transaksi saham di pasar modal syariah.

Pasar modal syariah merupakan salah satu alterntif tempat berinvestasi secara syariah, yang menjembatani perusahaan yang membutuhkan modal dengan investor yang mencari laba (Husnan, 2004; Sundaja, et.al., 2010); Sunariyah, 2003, Muslich: 2003). Pasar modal syariah merupakan suatu sistem yang terintegrasi dari sistem pasar modal secara keseluruhan, namun memiliki karakteristik khusus yang sesuai dengan prinsip-prinsip syariah. Larangan riba, maysir, dan gharar berlaku bagi produk, mekanisme transaksi, perusahaan publik lembaga dan profesi terkait (Sholihin, 2010). Salah satu ciri pasar modal syariah adalah adanya indeks syariah, yaitu Indeks Saham Syariah Indonesia (ISSI) dan Jakarta Islamic Index (JII). ISSI merupakan kapitalisasi pasar dari seluruh saham perusahaan dengan prinsip syariah yang terdaftar di Bursa Efek Indonesia (BEI), sedangkan JII hanya terdiri dari 30 perusahaan yang merupakan saham blue-chip (Darmaji dan Fakhruddin, 2011; IDX, 2016, Saputra, 2012).

Investor menerima kompensasi dalam bentuk laba (dividen) atas modal yang disetornya melalui saham yang dibelinya. Jadi, perusahaan harus menetapkan kebijakan dividen untuk menentukan besarnya dividen yang dibayarkan dan laba ditahan untuk kepentingan ekspansi perusahaan. Investor tentu menginginkan pembayaran dividen yang lebih tinggi, namun di satu sisi perusahaan juga harus mempertimbangkan besarnya laha ditahan untuk kontinuitas usaha (Suroto, 2015). Idealnya, penentuan jumlah dividen relatif terhadap laba bersih per lembar saham perusahaan (Keown, et.al, 2005).

Beberapa teori yang terkait dengan kebijakan dividen, antara lain Dividend Irrelevance Theory yang diperkenalkan oleh Miller dan Modigliani. Inti teori ini adalah tinggi rendahnya nilai dividen yang dibagikan kepada investor tidak berpengaruh terhadap nilai perusahaan. Teori ini didasarkan pada asumsi bahwa tidak ada pajak yang dibayar atas dividen, tidak ada biaya transaksi atas transaksi saham, dan terdapat simetri informasi tentang laba perusahaan di masa depan (Brigham dan Houston, 2011). Dalam Bird in the hand theory, Gordon dan Lintner mengemukakan dividen lebih baik daripada capital gain karena dividen lebih pasti sehingga kurang berisiko, sedangkan capital gain berisiko tinggi karena penuh ketidakpastian di masa 
datang (Wild, et.al., 2009). Teori lainnya terkait dengan dividen adalah Tax preference theory. Teori ini didasarkan atas pada perbedaan pajak antara dividen dengan capital gain. Pajak atas dividen harus dibayarkan pada tahun saat dividen tersebut diterima, sedangkan pajak atas capital gain tidak dibayarkan sampai saham dijual. Dengan demikian, investor akan lebih memilih capital gain daripada dividen. Nmaun secara umum, kebijakan dividen adalah salah satu cara mengurangi biaya keagenan, karena pembayaran dividen yang tinggi menjadi daya tarik investor untuk membeli saham sehingga kesempatan perusahaan memperoleh dana dari sumber eksternal semakin besar (Crutchley dan Hansen, 1989). Beberapa faktor berpengaruh terhadap kebijakan dividen antara lain (Riyanto, 2001):

a. Posisi likuiditas yang baik berkaitan positif terhadap pembayaran dividen yang tinggi.

b. Kebutuhan danayang besar untuk membayar hutang berakibat negatif terhadap pembayaran dividen.

c. Tingkat ekspansi perusahaan yang agresif menyebabkan pembayaran dividen semakin rendah.

d. Pengawasan terhadap perusahaan yang mempercayakan pada pembelanjaan internal menyebabkan pembayaran dividen semakin rendah.

Salah satu proksi kebijakan dividen adalah Dividend Payout Ratio (DPR) yang merupakan persentase laba yang dibayarkan dalam bentuk dividen (Sundaja, et.al., 2002; Irawanti, 2006; Baridwan, 2004; Warsono, 2003; Wild, et.al., 2009). Sedangkan likuiditas menunjukkan kemampuan perusahaan membayar utang jangka pendeknya, sesuai dengan siklus operasi normal suatu perusahaan, yaitu satu tahun (Wild, et.al., 2009). Banyak rasio yang digunakan untuk menganalisis tingkat likuiditas perusahaan, antara lain Current Ratio, Quick Ratio, dan Cash Ratio (Muslich, 2003, Sundaja, et.al., 2012).

Modal kerja merupakan salah satu sumber daya yang penting bagi perusahaan, seprti modal kerja bersih, yang merupakan selisih antara total aktiva lancar dengan total utang lancar. Modal kerja digunakan untuk membiayai operasi sehari-hari perusahaan, diharapkan dana yang telah dikeluarkan dapat kembali dalam jangka waktu yang relatif pendek (Raissa, 2012). Umumnya, aktiva lancar terdiri dari kas bank, surat-surat berharga yang mudah diuangkan (giro, cek, deposito), piutang dagang dan persediaan dengan tingkat perputarannya maksimal satu tahun (Sundaja, et.al., 2012). Beberapa faktor yang memengaruhi modal kerja adalah investasi perusahaan pada aktiva lancar, proporsi hutang jangka pendek, tingkat investasi pada tiap jenis aktiva lancar, sumber dana yang spesifik, dan komposisi utang lancar yang harus dipertahankan.

Likuiditas berkaitan erat dengan profitabilitas, karena likuiditas menunjukkan tingkat ketersediaan modal kerja perusahaan yang cukup sehingga perusahaan tidak mengalami kesulitan beroperasi (Hadiwidjaja, 2008; Bisma, 2009; Baramuli, 2016). Namun di satu sisi, kelebihan modal kerja menunjukkan manajemen perusahaan tidak optimal karena terdapat dana yang tidak produktif. Manajemen harus memastikan tersedianya modal kerja perusahaan yang cukup, sehingga tidak kekurangan modal dan juga tidak ada dana yang menganggur (Wild, et.al., 2009).

Modal kerja dan kebijakan dividen merupakan fungsi yang saling menunjang secara tidak langsung dalam perusahaan (Yulenda, et.al, 2017; Widnyana, 2015). Namun penelitian Oladipopu dan Ibadin (2013) menunjukkan bahwa modal kerja tidak berpengaruh terhadap kebijakan dividen. Sedangkan, modal kerja memiliki hubungan positif terhadap likuiditas, karena tingkat likuiditas yang baik menunjang modal kerja yang sehat (Supriadi dan Fazriani, 2013). Di lain pihak, likuiditas memiliki pengaruh yang negatif terhadap kebijakan dividen yang diproksi dengan Dividend Payout Ratio (DPR) (Afriani, et.al., 2013), namun penelitian Hadiwidjaja (2008) dan Kadir (2010) menemukan bahwa likuiditas tidak berpengaruh terhadap Dividend Payout Ratio (DPR). Sebaliknya, penelitian Pramana dan Sukartha (2015) dan Baramuli (2016) menemukan bahwa likuiditas berpengaruh positif terhadap Dividend Payout Ratio (DPR). 
Ahmad Rijal, dan Salmah Said. Efektifitas Modal Kerja dan Liquiditas...

Selanjutnya, penelitian Andanarini dan Safitri menunjukkan modal kerja berpengaruh negatif terhadap likuiditas perusahaan (Andanarini dan Safitri, 2013).

\section{METODE PENELITIAN}

Jenis penelitian ini merupakan penelitian asosiatif yang menganalisis relasi antara modal kerja (Net Working Capital) terhadap kebijakan dividen (Dividend Payout Ratio) melalui likuiditas (Current Ratio) sebagai variabel intervening (Riyanto, 2001). Data yang dianalisis merupakan data sekunder yang diperoleh dari website BEI dan masing-masing perusahaan. Objek penelitian ini adalah perusahaan yang berbasis syariah yang konsisten terdaftar di JII, yaitu 30 perusahaan. Dengan metode purposive sampling diperoleh sampel sebanyak 12 perusahaan yang konsisten terdaftar di JII selama periode 2011 - 2014, seperti ditunjukkan dalam tabel berikut:

Tabel 2. Daftar Perusahaan Sampel Penelitian

\begin{tabular}{ccl}
\hline No & Kode Perusahaan & \multicolumn{1}{c}{ Nama Perusahaan } \\
\hline 1 & AALI & PT. Astra Agro Lestari Tbk. \\
2 & ASII & PT. Astra International Tbk. \\
3 & CPIN & PT. Charoen Pokphand Indonesia Tbk. \\
4 & INTP & PT. Indocement Tunggal Perkasa Tbk. \\
5 & ITMG & PT. IndoTambangraya Megah Tbk. \\
6 & KLBF & PT. Kalbe Farma Tbk. \\
7 & LSIP & PT. PP London Sumatera Indonesia Tbk. \\
8 & PTBA & PT. Tambang Batubara Bukit Asam Tbk. \\
9 & SMGR & PT. Semen Gresik (Persero) Tbk. \\
10 & TLKM & PT. Telekomunikasi Indonesia (Persero) Tbk. \\
11 & UNTR & PT. United Tractors Tbk. \\
12 & UNVR & PT. Unilever Indonesia Tbk \\
\hline
\end{tabular}

Metode analisis yang digunakan adalah analisis regresiberganda untu mengevaluasi relasi kausal variabel bebas (modal kerja dan likuiditas) terhadap variabel terikat (kebijakan dividen) (Sugiyono, 2011:261). Model persamaannya adalah sebagai berikut:

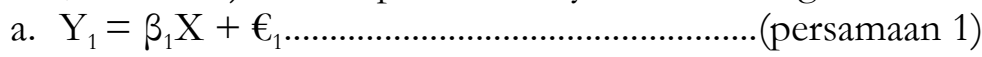

b. $Y_{2}=\beta_{1} X+\beta_{2} Y_{1}+€_{2} \ldots \ldots \ldots \ldots \ldots \ldots \ldots \ldots \ldots \ldots \ldots \ldots \ldots \ldots . . .($ persamaan 2$)$

Keterangan:

$\mathrm{Y}_{2}=$ Dividend Payout Ratio (\%)

$\mathrm{Y}_{2}=$ Current Ratio (\%)

$\mathrm{X}=$ Modal Kerja Bersih (Net Working Capital)

$€=$ Residual

$\beta 1, \beta 2,=$ Koefisien Regresi

Disamping itu, penelitian ini juga menggunakan analisis jalur, untuk menguji besarnya sumbangan (kontribusi) yang ditunjukkan oleh koefisien jalur pada setiap diagram jalur dari hubungan kausal antar variabel $\mathrm{X}_{1}$ terhadap $\mathrm{X}_{2}$ melalui $\mathrm{Y}_{1}$ (Sarwono, 2007; Ghozali, 2005, Sunyoto, 2009). Selain itu, penelitian juga ini menggunakan uji asumsi klasik untuk memastikan variabel yang digunakan memenuhi ketentuan uji asumsi klasik (normalitas, multikolinearitas, autokorelasi, heterokedastisitas, dan linearitas) sehingga variabel layak digunakan dalam menganalisis pengaruh modal kerja terhadap kebijakan dividen melalui likuditas sebagai variabel intervening (Ghozali, 2005:91-105). Model persamaan analisis jalur digambarkan sebagai berikut: 


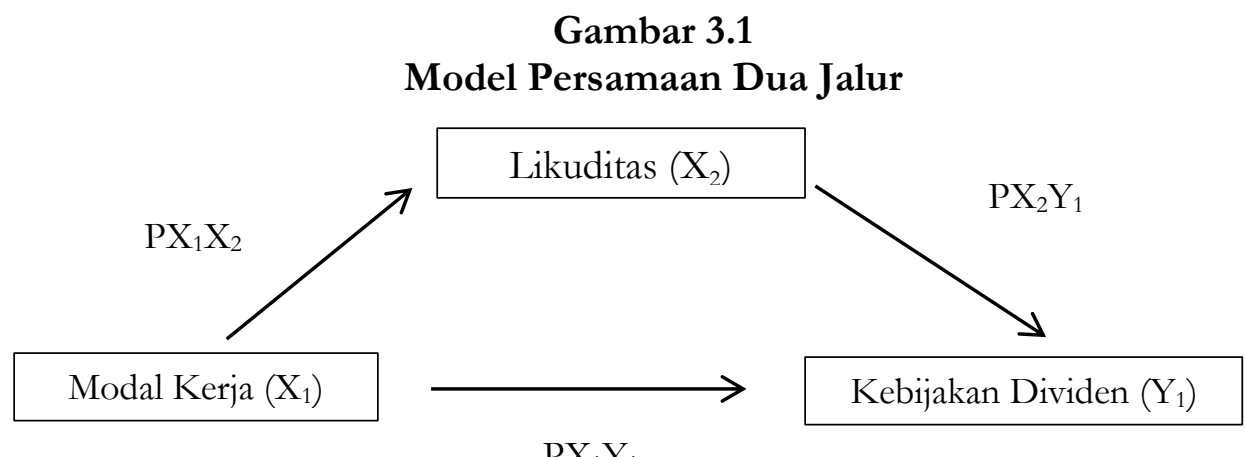

Kontribusi variasi variabel modal kerja melalui variabel likuiditas berpengaruh terhadap variasi variabel kebijakan dividen dianalisis melalui koefisien determinasi (Priyatno, 2008:81). Hipotesis dianalisis dengan uji $t$ dan uji $f$ untuk menganalisis pengaruh variabel modal kerja melalui likuiditas secara parsial dan secara simultan terhadap variabel kebijakan dividen.

\section{HASIL DAN PEMBAHASAN}

Sampel penelitian ini sebanyak 12 perusahaan yang konsisten terdaftar di JII selama periode 2011-2014, dengan berbagai sektor industri. Perusahaan sampel tersebut adalah(Bursa Efek Indonesia, 2016): 1). PT. Astra Agro Lestari Tbk. (industri pertanian dan perkebunan), 2). PT Astra International Tbk (industri otomotif), 3). PT Charoen Pokphand Indonesia Tbk (industri consumer goods), 4). PT Indocement Tunggal Prakarsa Tbk. (industri semen), 5). PT. IndoTambangraya Megah Tbk. (industri batubara), 6). PT. Kalbe Farma Tbk. (industri farmasi), 7). PT. PP London Sumatera Indonesia Tbk. (industri pertanian dan perkebunan), 8). PT. Tambang Batubara Bukit Asam Tbk. (industri batu bara), 9). PT. Semen Gresik (Persero) Tbk (industri semen), 10). PT. Telekomunikasi Indonesia (Persero) Tbk., (industri telekomunikasi), 11). PT. Unted Tractors, Tbk. (industri pertanian dan perkebunan), 12). PT. Unilever Indonesia Tbk. (industri consumer goods).

Hasil perhitungan keuangan variabel likuiditas (CR), modal kerja (NWC) dan kebijakan dividen (DPR) perusahaan JII selama 2011-2014, ditunjukkan pada tabel berikut:

Tabel 3. Data Rerata CR, NWC, dan DPR Perusahaan JII

\begin{tabular}{ccrrr}
\hline No & KODE & CR (\%) & \multicolumn{1}{c}{ NWC (Rp) } & DPR (\%) \\
\hline 1 & AALI & 75,73 & -1.042 .256 .000 .000 & 57,32 \\
2 & ASII & 133,20 & 20.039 .750 .000 .000 & 45,18 \\
3 & CPIN & 316,95 & 5.203 .810 .750 .000 & 26,01 \\
4 & INTP & 593,97 & 11.982 .746 .750 .000 & 56,30 \\
5 & ITMG & 203,47 & 4.460 .214 .000 .000 & 100,37 \\
6 & KLBF & 332,53 & 4.866 .810 .250 .000 & 55,00 \\
7 & LSIP & 327,05 & 1.536 .948 .250 .000 & 40,17 \\
8 & PTBA & 362,43 & 5.488 .993 .750 .000 & 53,20 \\
9 & SMGR & 211,10 & 4.803 .213 .750 .000 & 45,00 \\
10 & TLKM & 108,60 & 2.387 .250 .000 .000 & 67,70 \\
11 & UNTR & 190,84 & 12.978 .976 .250 .000 & 55,90 \\
12 & UNVR & 69,20 & -2.402 .983 .500 .000 & 86,20 \\
\hline
\end{tabular}

Sumber: Data diolah 
Ahmad Rijal, dan Salmah Said. Efektifitas Modal Kerja dan Liquiditas...

Tabel di atas menunjukkan rerata nilai kinerja keuangan perusahaan JII selama periode penelitian, yaitu nilai Current Ratio (CR), Dividend Payout Ratio (DPR), dan Net Working Capital (NWC). Hasil evaluasi keuangan ini menunjukkan bahwa likuditas perusahaan JII (yang diproksikan dengan rasio CR) termasuk baik karena nilainya di atas 100\%, kecuali perusahaan PT. Agro Lestari Tbk (AALI) dan PT. Unilever Tbk (UNVR) yang masing-masing hanya mencapai $75,73 \%$ dan $69,20 \%$. Hal ini berarti bahwa perusahaan JII mampu melunasi utangutang jangka pendeknya, rata-rata dua-tiga kali lipat karena total nilai asset lancarnya lebih besar daripada total nilai utang lancarnya. . Peningkatan ini dapat berasal dari meningkatnya penjualan tunai atau kredit yang menambah kas atau adanya pelunasan utang, sehingga utang lancar menurun. Perusahaan tersebut tidak mengalami kesulitan melunasi kewajiban lancarnya pada saat jatuh tempo Modal kerja ini digunakan untuk menjalankan operasional perusahaan sehari-hari sehingga perusahaan dapat berkembang sesuai dengan visi yang telah ditetapkan., Jadi dapat disimpulkan bahwa perusahaan yang terdaftar di JII mempunyai tingkat likuidasi yang tinggi.

Likuditas rendah terjadi pada PT. Astra Agro Lestari dan PT. Unilever Indonesia Tbk yang berada di bawah angka 100\%. Jadi, kedua kerusahaan tersebut tergolong tidak likuid karena aktiva lancarnya lebih rendah daripada utang lancarnya. Akibatnya, kedua perusahaan tersebut tidak mampu membayar utang jangka pendeknya. Hal ini sejalan dengan nilai modal kerja bersih yang dievaluasi melalui rasio Net Working Capital pada Tabel 3 rata-rata NWC PT. Astra Agro Lestari Tbk dan PT. Unilever Indonesia Tbk yang paling rendah atau bernilai negatif. Jadi, modal kerja bersih dan likuiditas memiliki hubungan positif.

Secara rerata, kinerja NWC perusahaan JII memiliki trend positif, selama periode penelitian, meskipun menurun pada tahun 2013 karena pelemahan nilai tukar rupiah terhadap dollar AS. Selama periode penelitian, NWC perusahaan JII senilai lebih dari Rp. 5 triliyun. Hal ini menunjukkan bahwa perusahaan JII memiliki proporsi modal kerja bersih yang semakin meningkat. Dengan demikian, secara umum perusahaan memiliki modal kerja yang baik untuk operasional perusahaan

Sedangkan ke-10 perusahaan lainnya memiliki likuiditas yang cukup memadai, karena nilai Current Ratio di atas 100\%. Hal ini berarti bahwa perusahaaan mampu membayar utang jangka pendeknya, karena aktiva lancar lebih besar dari utang lancarnya. Nilai Current Ratio tertinggi pada PT. Indocement Tunggal Perkasa Tbk karena adanya peningkatan aktiva lancar. Secara rerata, Current Ratio perusahaan JII di atas $200 \%$.

Tabel 3 juga menunjukkan nilai DPR perusahaan JII yang sebagian besar di atas 50\%. Dengan kata lain, perusahaan hanya membagi setengah laba bersih yang dihasilkan ke pemegang saham dalam bentuk dividen, dan setengahnya lagi digunakan untuk ekspansi perusahaan. Hal ini merupakan sinyal positif bagi investor bahwa perusahaan berusaha melakukan ekspansi usaha dalam rangka mempertahankan pembayaran dividen yang rutin setiap tahunnya.

Dari 12 perusahaan sampel penelitian ini, DPR dari PT. Indocement Tunggal Perkasa Tbk mengalami trend positif selama periode penelitian. Kondisi ini memperlihatkan kemampuan perusahaan menjaga likuiditas dan proftabilitasnya dengan baik, sehingga para investor dapat menikmati dividen sesuai dengan prosentase jumlah kepemilikan sahamnya. Sebaliknya, secara rerata nilai DPR dari PT. Unilever Indonesia Tbk memiliki trend negatif, karena perusahaan membutuhkan dana besar dari laba ditahan untuk membayar utang. Hal ini menyebabkan persentase dividen yang dibagikan menjadi rendah. Selain itu, posisi likuiditas perusahaan yang kurang baik juga mengakibatkan rendahnya dividen. Posisi kas yang semakin rendah menyebabkan turunnya pembayaran dividen.

Selain analisis keuangan, peneliti juga melakukan uji asumsi klasik. Hasil pengujian asumsi klasik dirangkum dalam Tabel 4 berikut. Hasil uji statistik Kolmogorov-Smirnov 
AL-MASHRAFIYAH: Jurnal Ekonomi, Keuangan, dan Perbankan Syariah Volume 2, Nomor 2, Oktober 2018

menunjukkan bahwa variabel pengujian terdistribusi secara normal, karena memiliki signifikansi 0,137 yang lebih besar dari 0,05.

Tabel 4. Ringkasan Nilai Statistic Uji Asumsi Klasik Perusahaan JII

\begin{tabular}{|c|c|c|c|c|c|}
\hline & \multirow[t]{2}{*}{ Nilai statistik. } & \multicolumn{2}{|c|}{ Collinearity Statistics } & \multirow{2}{*}{$\begin{array}{l}\text { Durbin- } \\
\text { Watson }\end{array}$} & \multirow{2}{*}{$\begin{array}{l}\text { Glejser } \\
\text { Sig. }\end{array}$} \\
\hline & & Tolerance & $V I F$ & & \\
\hline $\begin{array}{l}\text { Kolmogorov-Smirnov } \\
Z\end{array}$ & 1.158 & & & & \\
\hline Asymp. Sig. (2-tailed) & 0.137 & & & & \\
\hline Constant & & & & & 0.003 \\
\hline$N W C$ & & 0.931 & 1.074 & & 0.402 \\
\hline$C R$ & & 0.931 & 1.074 & & 0.859 \\
\hline & & & & 1.97 & \\
\hline
\end{tabular}

Sumber: Analisis data primer setelah diolah

Untuk menganalisis variabel penelitian tidak memiliki masalah multikolinearitas, maka dilakukan pengujian dengan nilai Variance Inflactor Factor (VIF) yang kurang dari 10 dan nilai tolerance lebih dari 0,10. Dari tabel berikut diketahui bahwa nilai VIF untuk variabel NWC (Net Working Capital) sebesar 1,074 $<10$ dan nilai Tolerance sebesar $0.931>$ dari 0,10 sehingga dapat disimpulkan tidak terjadi multikolinearitas. Selain itu, nilai VIF untuk variabel CR (Current Ratio) sebesar $1,074<10$ dan nilai Tolerance sebesar $0.931>$ dari 0,10 sehingga dapat disimpulkan tidak terjadi multikolinearitas.

Uji asumsi klasik lainnya yaitu uji heteroskedastisitas juga dilakukan untuk mengetahui apakah dalam model regresi terjadi ketidaksamaan varians residual dari satu pengamatan ke pengamatan yang lain. Untuk itu digunakan Uji Glejser, yaitu dengan cara meregresikan antara variabel independen dengan nilai absolut residualnya. Jika nilai signifikansi antara variabel bebas (independent) dengan absolut residual lebih dari 0,05 maka tidak terjadi masalah heteroskedastisitas.

Hasil uji heterokedastisitas dengan Uji Glejser ditunjukkan Tabel 4 di atas, yaitu nilai signifikansi variabel NWC sebesar 0,402 lebih besar dari 0,05 artinya tidak terjadi heterokedastisitas dan nilai signifikansi variabel CR sebesar 0,859 lebih besar dari 0,05 artinya tidak terjadi heterokedastisitas. Jadi dapat disimpulkan bahwa variabel bebas dari penelitian ini tidak terjadi masalah heterokedastisitas.

Terakhir, uji autokorelasi juga dilakukan untuk mengetahui adanya korelasi antara variabel gangguan sehingga penaksir tidak lagi efisien baik dalam model sampel kecil maupun dalam sampel besar. Salah satu cara untuk menguji autokorelasi adalah dengan percobaan Durbin-Watson dengan ketentuan sebagai berikut:

1. Jika d lebih kecil dari dL atau lebih besar dari (4-dL) maka hipotesis nol ditolak,yang berarti terdapat autokorelasi.

2. Jika d terletak antara dUdan (4-dU),maka hipotesis nol diterima, yang berarti tidak ada autokorelasi.

3. Jika d terletak antara dL dan dU atau di antara (4-dU) dan (4-dL), maka tidak menghasilkan kesimpulan yang pasti.

Tabel 4 di atas menunjukkan bahwa nilai Durbin-Watson pada penelitian ini sebesar 1,970 lebih besar dari batas dU yakni 1,6231 (Sign 5\%, K=2 dan N=48) dan kurang dari nilai (4 $\mathrm{dU})=4-1,6231$ sebesar 2,3769 sehingga dapat disimpulkan bahwa tidak terjadi autokorelasi. 
Ahmad Rijal, dan Salmah Said. Efektifitas Modal Kerja dan Liquiditas...

Uji statistik berikutnya adalah uji model dengan analisis sub struktur 1 . Tabel 5 menunjukkan uji koefisien determinasi $\left(\mathrm{R}^{2}\right)$. Besarnya angka $\mathrm{R}$ Adjusted Square $\left(\mathrm{R}^{2}\right)$ digunakan untuk melihat besarnya pengaruh variabel modal kerja (Net Working Capital) terhadap likuditas (Current Ratio). Berdasarkan tabel di bawah nilai $R$ Adjusted Square menunjukkan angka 0,048 $\times$ $100 \%=4,8 \%$. Hal ini mengindikasikan bahwa kontribusi variabel independen yaitu modal kerja (Net Working Capital) terhadap variabel dependen yaitu likuiditas (Current Ratio) adalah $4,8 \%$ sedangkan $95,2 \%$ dipengaruhi faktor lain.

Tabel 5. Hasil Uji Koefisien Determinasi $\left(\mathbf{R}^{2}\right)$ Sub Struktur 1

\begin{tabular}{lcccc}
\hline Model & $\mathrm{R}$ & $\mathrm{R}$ Square & $\begin{array}{c}\text { Adjusted } \mathrm{R} \\
\text { Square }\end{array}$ & Std. Error of the Estimate \\
\hline 1 &, $262^{\mathrm{a}}$ &, 069 &, 048 & \\
\hline a. Predictors: (Constant), NWC & & & \\
b. Dependent Variabel: CR & & & \\
Sumber:Output SPSS 23 & & &
\end{tabular}

Tabel 6 berikut menggambarkan uji t (parsial) Sub Struktur 1 yang menunjukkan bahwa variabel $\mathrm{X}_{1}$ mempunyai tingkat signifikan $0,072>0,05$ dan koefisien $\beta=0,262$. sehingga dapat dikatakan bahwa hubungan antara $\mathrm{X}_{1}$ dengan $\mathrm{X}_{2}$ tidak signifikan. Untuk menganalisis seberapa besar pengaruh variabel lain terhadap likuiditas (Current Ratio), dapat ditentukan dengan cara berikut:

$$
\begin{aligned}
\mathrm{PX}_{2} €_{1} & =\sqrt{1}-\mathrm{R}^{2} \mathrm{X}_{2} \mathrm{X}_{1} \\
& =1-0,048=0.952=95,2 \%
\end{aligned}
$$

Nilai $\left(\mathrm{PX}_{2} €_{1}\right)$ koefisien jalur variabel lain terhadap likuidatas (Current Ratio), pada perusahaan yang terdaftar secara konsisten pada Jakarta Islamic Index di Bursa Efek Indonesia sebesar 95,2\%, artinya 95,2\% dipangaruhi faktor lain diluar model substruktur 1, misalnya jangka waktu pembayaran utang, pembelian aktiva tetap, kondisi perekonomian suatu negara, sehingga pengaruh modal kerja terhadap likuiditas dalam penelitian ini sangat kecil. Persamaan jalur substruktur 1 adalah:

$$
\mathrm{X}_{2}=0,262 \mathrm{X}_{1}+€ 0,952
$$

\begin{tabular}{|c|c|c|c|c|c|c|}
\hline \multirow{2}{*}{\multicolumn{2}{|c|}{ Model }} & \multicolumn{2}{|c|}{ Unstandardized Coefficients } & $\begin{array}{c}\text { Standardized } \\
\text { Coefficients }\end{array}$ & \multirow[t]{2}{*}{$t$} & \multirow[t]{2}{*}{ Sig. } \\
\hline & & $B$ & Std. Error & Beta & & \\
\hline \multirow{2}{*}{1} & (Constant) & 205,644 & 30,290 & & 6,789 & 000 \\
\hline & NWC & $6,503 \mathrm{E}-12$ & ,000 & ,262 & 1,842 & ,072 \\
\hline
\end{tabular}

Tabel 6. Hasil Uji $\mathbf{t}_{\text {hitung }}$ Sub Struktur 1

a. Dependent Variable: CR

Sumber: Output SPSS 23

Langkah selanjutnya adalah melakukan analisis sub struktur 2 dengan menguji koefisien determinasi $\left(\mathrm{R}^{2}\right)$. Tabel 7 berikut menunjukkan bahwa nilai $\mathrm{R}$ Adjusted Square menunjukkan angka $0,018 \times 100 \%=1,8 \%$. Hal ini mengindikasikan bahwa kontribusi variabel independen yaitu modal kerja (Net Working Capital) dan likuiditas (Current Ratio) terhadap variabel dependen yaitu kebijakan dividen (Dividend Payout Ratio) adalah 1,8\% sedangkan 98,2\% dipengaruhi faktor lain. 
AL-MASHRAFIYAH: Jurnal Ekonomi, Keuangan, dan Perbankan Syariah Volume 2, Nomor 2, Oktober 2018

Tabel 7. Hasil Uji Koefisien Determinasi $\left(\mathbf{R}^{2}\right)$ Sub Struktur 2

\begin{tabular}{|c|c|c|c|c|}
\hline Model & $R$ & $R$ Square & $\begin{array}{l}\text { Adjusted } \\
R \text { Square }\end{array}$ & Std. Error of the Estimate \\
\hline 1 & $245^{a}$ &, 060 & ,018 & 29,72917 \\
\hline
\end{tabular}

Uji simultan (uji F) dilakukan pada sub struktur 2 yang ditunjukkan oleh Tabel 8 berikut. Dari tabel tersebut diketahui bahwa nilai F sebesar 1,442 dengan nilai signifikan yaitu 0,247 > 0,05. Hal ini menunjukkan bahwa variabel modal kerja (Net Working Capital), likuiditas (Current Ratio) tidak memengaruhi secara stimultan variabel dependen yakni kebijakan dividen (Dividend Payout Ratio).

Tabel 8. Hasil Uji F Substruktur 2

\begin{tabular}{llrrrrr}
\hline Model & & Sum of Squares & Df & Mean Square & $F$ & Sig. \\
\hline 1 & Regression & 2548,962 & 2 & 1274,481 & 1,442 &, $247^{\mathrm{b}}$ \\
& Residual & 39772,068 & 45 & 883,824 & & \\
& Total & 42321,030 & 47 & & & \\
\hline
\end{tabular}

a. Dependent Variable: DPR

b. Predictors: (Constant), CR, NWC

Sumber:Output SPSS 23

Hasil uji parsial (uji t) pada substruktur 2 ditunjukkan pada Tabel 9 berikut.

Tabel 9.Hasil Uji $t_{\text {hitung }}$ Substruktur 2 Coefficients ${ }^{\mathrm{a}}$

\begin{tabular}{|c|c|c|c|c|c|c|}
\hline & \multirow[t]{2}{*}{ Model } & \multicolumn{2}{|c|}{ Unstandardized Coefficients } & $\begin{array}{c}\text { Standardized } \\
\text { Coefficients }\end{array}$ & \multirow[t]{2}{*}{$t$} & \multirow[t]{2}{*}{ Sig. } \\
\hline & & B & Std. Error & Beta & & \\
\hline \multirow[t]{3}{*}{1} & (Constant) & 69,330 & 8,314 & & 8,338 & , 000 \\
\hline & NWC & $-5,473 \mathrm{E}-13$ &, 000 &,- 115 &,- 771 & ,445 \\
\hline & CR &,- 036 & ,038 &,- 118 & $-1,358$ & 215 \\
\hline
\end{tabular}

a. Dependent Variable: DPR

Sumber:Output SPSS 23

Tabel 9 di atas menunjukkan hasil uji t (pengaruh variabel $\mathrm{X}$ terhadap variabel $\mathrm{Y}$ ) yaitu:

a. Pengaruh modal kerja (Net Working Capital) terhadap kebijakan dividen (Dividend Payout Ratio), dari hasil olah data di atas diperoleh nilai $t_{\text {hitung }}=-0,771$, pada tabel diatas nilai signifikan sebesar $0,445>0,05$ dan $\beta=-0,115$ artinya tidak berpengaruh secara signifkan dan negatif.

b. Pengaruh likuiditas (Current Ratio) terhadap kebijakan dividen (Dividend Payout Ratio), dari hasil olah data di atas diperoleh nilai $t_{\text {hitung }}=-1,358$ pada tabel di atas nilai signifikan sebesar 0,215 $>0,05$ dan $\beta=-0,188$ artinya tidak berpengaruh dan negatif signifikan.

Untuk menentukan adanya pengaruh variabel lain terhadap kebijakan dividen (Dividend Payout Ratio), maka dapat ditentukan dengan cara:

$$
\begin{aligned}
\mathrm{PY}_{2} & =\sqrt{1}-\mathrm{R}^{2} \mathrm{YX}_{2} \mathrm{X}_{1} \\
& =\sqrt{1}-0,018 \\
& =0,982 \times 100 \%
\end{aligned}
$$


Ahmad Rijal, dan Salmah Said. Efektifitas Modal Kerja dan Liquiditas...

$$
=98,2 \%
$$

Sehingga persamaan jalur pada substruktur 2 ini adalah:

$$
\mathrm{Y}=-0,115 \mathrm{X}_{1}+(-0,118) \mathrm{X}_{2}+€ 0,982
$$

Untuk mengetahui adanya pengaruh secara langsung atau tidak langsung adalah sebagai berikut:

a. Variabel modal kerja

Pengaruh langsung

$\mathrm{X}_{1}$ terhadap $\mathrm{Y}=\mathrm{Y} \leftarrow \mathrm{X}_{1} \rightarrow \mathrm{Y}=\left(\mathrm{PYX}_{1}\right)\left(\mathrm{PYX}_{1}\right)$

$$
=(-0,115)(-0,115)
$$

Variabel intervening likuiditas

$$
=0,013225=1,3225 \%
$$

Pengaruh langsung

$$
\begin{aligned}
\mathrm{X}_{2} \text { terhadap } \mathrm{Y}=\mathrm{Y} \leftarrow \mathrm{X}_{2} \rightarrow \mathrm{Y} & =\left(\mathrm{PYX}_{2}\right)\left(\mathrm{PYX}_{2}\right) \\
& =(-0,188)(-0,188) \\
& =0,035244=3,5344 \%
\end{aligned}
$$

b. Pengaruh tidak langsung modal kerja terhadap kebijakan dividen melalui likuiditas

$\mathrm{X}_{1}$ terhadap $\mathrm{Y}$ melalui $\mathrm{X}_{2}=\mathrm{Y} \leftarrow \mathrm{X}_{1} \Omega \mathrm{X}_{2} \rightarrow \mathrm{Y}$

$$
\begin{aligned}
& =\left(\mathrm{PYX}_{1}\right)\left(\mathrm{PX}_{1} \mathrm{X}_{2}\right)\left(\mathrm{PYX}_{2}\right) \\
& =(-0,115)(0,262)(-0,188) \\
& =(0,00566444) \times 100 \% \\
& =0,566444 \%
\end{aligned}
$$

Hasil perhitungan di atas menunjukkan pengaruh langsung dan pengaruh tidak langsung antar variabel dalam penelitian. Pengaruh langsung modal kerja terhadap kebijakan dividen sebesar $1,3325 \%$ dan pengaruh modal kerja melalui likuiditas sebagai variabel intervening terhadap kebijakan dividen sebesar $(0,00566444) \times(0,035244)=0,0001996375 \times 100 \%=$ $0,0199637523 \%$ atau 0,02\% (pembulatan). Dari hasil uji t dan uji $\mathrm{F}$ dapat dilakukan uji hipotesis, sebagai berikut:

\section{a. Pengujian $\mathbf{H}_{1}=$ Modal kerja tidak berpengaruh terhadap kebijakan dividen.}

Berdasarkan hasil tabel $t_{\text {hitung }}$ pada sub struktur 2 pada Tabel 14 dapat dilihat bahwa modal kerja yang diukur dengan menggunakan Net Working Capital memliki nilai $t_{\text {hitung }}$ sebesar $-0,771$, dan nilai signifikan sebesar $0,445>0,05$. Hal ini berarti bahwa modal kerja tidak memiliki pengaruh terhadap kebijakan dividen dan negatif. Jadi, $\mathrm{H}_{1}$ diterima.

Dari hasil uji analisis jalur (path analysis), dapat diuraikan pengaruh variabel modal kerja dengan proksi NWC terhadap kebijakan dividen dengan proksi DPR. Hasil pengujian regresi menunjukkan bahwa variabel modal kerja yang diukur dengan Net Working Capital tidak memiliki pengaruh terhadap kebijakan dividen yang diukur dengan Dividend Payout Ratio. Hasil ini sesuai dengan penelitian yang dilakukan oleh Adesina Olugoke Oladipopu dan Peter Okeouguale Ibadin (2013) yang menyatakan bahwa, modal kerja tidak berpengaruh terhadap kebijakan dividen, meskipun terdapat hubungan yang tidak secara langsung antara modal kerja dan kebijakan dividen dalam perusahaan (Yulenda, et.al, 2017; Widnyana, 2015). Hal ini membuktikan bahwa dalam kebijakan dividen tidak ada pengaruhnya dari kebutuhan modal kerja pada setiap perusahaan. Jadi, kebijakan dividen yang ditempuh oleh berbagai perusahaan biasanya dipengaruhi oleh posisi likuiditas, kebutuhan dana untuk membayar hutang, kemampuan dalam menghasilkan laba pada setiap perusahaan dan ekspansi perusahaan. Kebijakan dividen memegang peranan penting dalam mensejahterkan para pemegang saham di samping memperoleh laba dalam operasional perusahaan. 
AL-MASHRAFIYAH: Jurnal Ekonomi, Keuangan, dan Perbankan Syariah Volume 2, Nomor 2, Oktober 2018

\section{b. Pengujian $\mathbf{H}_{2}=$ Modal kerja berpengaruh terhadap likuiditas.}

Berdasarkan hasil uji t yang telah dilakukan pada Tabel 4.9, nilai $t_{\text {hitung }}$ sebesar 1,842 dengan signifikansi sebesar 0,072 , nilai signifikansi di atas 0,05 menunjukkan bahwa variabel modal kerja yang diukur dengan Net Working Capital tidak memiliki pengaruh dan tidak signifikan terhadap likuiditas yang diukur dengan Current Ratio. Jadi, $\mathrm{H}_{2}$ ditolak.

Menurut beberapa penelitian (Hadiwidjaja, 2008; Bisma, 2009; Baramuli, 2016), kondisi likuiditas perusahaan tidak dapat dipisahkan dengan tingkat profitabilitas, karena likuiditas menunjukkan tingkat ketersediaan modal kerja perusahaan yang cukup untuk dapat menghasilkan keuntungan. Sedangkan pengaruh modal kerja (NWC) terhadap likuiditas (CR) ditunjukkan dari hasil pengujian regresi yang menunjukkan bahwa variabel modal kerja yang diukur dengan Net Working Capital tidak memiliki pengaruh terhadap likuiditas yang diukur dengan Current Ratio. Hal ini sesuai dengan penelitian yang dilakukan oleh Yulsiaty dan Aulia (2015) yang menyatakan bahwa modal kerja tidak berpengaruh terhadap likuiditas. Modal kerja memiliki hubungan positif terhadap likuiditas, karena tingkat likuiditas yang baik menunjang modal kerja yang sehat Kebutuhan modal kerja (NWC) tidak berpengaruh terhadap likuiditas perusahaan karena Net Working Capital yang dimiliki oleh setiap JII. Selain itu, nilai Current Ratio perusahaan yang tinggi membuktikan kemampuan perusahaan mengelola kebutuhan modal kerja dan likuiditas perusahaan dengan baik, sehingga operasional perusahaan dapat berjalan dengan baik. Namun, hasil penelitian ini tidak sejalan dengan penelitian Supriadi dan Fazriani (2013), yang menyatakan bahwa modal kerja berpnegaruh positif terhadap likuiditas. Penelitian ini juga tidak sejalan dengan hasil penelitian Andanarini dan Safitri (2013) yang menunjukkan modal kerja berpengaruh negatif terhadap likuiditas perusahaan.

\section{c. Pengujian $\mathrm{H}_{3}=$ Likuiditas berpengaruh terhadap kebijakan dividen.}

Berdasarkan hasil uji t yang telah dilakukan pada Tabel 4.12, nilai $t_{\text {hitung }}$ sebesar $-1,258$ dengan signifikansi sebesar 0,215 , nilai signifikansi di atas 0,05 menunjukkan bahwa variabel likuditas yang diukur dengan Current Ratio tidak memiliki pengaruh dan negatif dan tidak signifikan terhadap likuditas yang diukur dengan Current Ratio. Jadi, $\mathrm{H}_{3}$ ditolak.

Modal kerja memiliki hubungan erat dengan likuiditas. Di satu sisi, modal kerja yang cukup memberi peluang bagi perusahaan untuk memenuhi kewajiban-kewajiban jangka pendeknya. Di sisi lainnya, likuiditas perusahaan yang baik menunjukkan kemampuannya untuk membayar utang-utang yang harus segera dilunasi. Dengan demikian, modal kerja perusahaan harus digunakan secara produktif asehingga idle fund tidak terjadi dan pada saat yang sama tingkat likuiditas harus dijaga untuk memastikan utang lancar dapat dilunasi. Hal ini dapat terwujud apabila nilai aktiva lancar lebih besar dibanding pada utang lancar.

Hasil pengujian regresi penelitian ini menunjukkan bahwa variabel Current Ratio sebagai proksi likuiditas tidak berpengaruh terhadap variabel Dividend Payout Ratio sebagai proksi dari kebijakan dividen. Hal ini sejalan dengan penelitian yang dilakukan oleh Hadiwidjaja (2008) dan Kadir (2010) yang menemukan bahwa likuiditas tidak berpengaruh terhadap Dividend Payout Ratio (DPR). Likuiditas menggambarkan bahwa kewajiban-kewajiban jangka pendek perusahaan mampu dipenuhi tepat waktu. Hal ini penting karena pepmbayaran dividen memerlukan cashoutflow. Hal ini dapat dilakukan apabila perusahaan memiliki tingkat likusitas yang tinggi, karena perusahan juga harus memastikan operasional perusahaan dapat berjalan baik pada saat dividen dibayarkan kepada investor. Secara teori, hubungan pembayaran dividen terkait erat dengan likuditas, karena Current Ratio terdapat kas sebagai salah satu sumber untuk pembayaran dividen, meskipun nilai Current Ratio juga dipengaruhi oleh beberapa akun seperti piutang dan persediaan. Lebih lanjut, Current Ratio menggambarkan kemampuan aset lancar perusahaan untuk memenuhi utang jangka pendek, bukan pada kemampuan untuk membagikan dividen kas. Semakin tinggi nilai Current Ratio menunjukkan kemampuan 
Ahmad Rijal, dan Salmah Said. Efektifitas Modal Kerja dan Liquiditas...

perusahaan untuk melunasi utang lancarnya semakin besar, demikian sebaliknya. Namun, penelitian ini tidak mendukung hasil penelitian Pramana dan Sukartha (2015) dan Baramuli (2016) yang menemukan bahwa likuiditas berpengaruh positif terhadap Dividend Payout Ratio (DPR). Lebih lanjut, penelitian ini juga tidak sejalan dengan penelitian Afriani, et.al., (2013), yang menyimpulkan bahwa likuiditas memiliki pengaruh yang negatif terhadap kebijakan dividen yang diproksi dengan Dividend Payout Ratio (DPR).

\section{d. $\mathbf{H}_{4}=$ Modal kerja tidak berpengaruh terhadap kebijakan dividen melalui likuiditas.}

Hasil perhitungan pengaruh tidak langsung modal kerja terhadap kebijakan dividen dengan likuiditas sebagai variabel intervening sebesar $(0,00566444) \times(0,035244)=$ 0,0001996375. Pengaruh tidak langsung modal kerja terhadap kebijakan dividen melalui likuiditas dengan pengaruh langsung modal kerja terhadap kebijakan dividen didapatkan hasil 0,013225, sehingga 0,0001996375 < 0,013225. Jadi dapat dinyatakan bahwa likuiditas yang diukur dengan Current Ratio tidak dapat memediasi pengaruh modal kerja yang diukur dengan Net Working Capital terhadap kebijakan dividen yang diukur dengan Dividen Payout Ratio sehingga $\mathrm{H}_{4}$ diterima.

Pengaruh modal kerja terhadap kebijakan dividen melalui likuiditas ditunjukkan dari hasil uji model menunjukkan bahwa likuiditas (Current Ratio) tidak dapat memediasi pengaruh modal kerja (Net Working Capital) terhadap kebijakan dividen (Dividend Payout Ratio). Dengan kata lain, penambahan variabel likuiditas sebagai variabel intervening tidak memengaruhi modal kerja yang digunakan setiap perusahaan menjalankan operasionalnya terhadap keputusan pembayaran dividen kepada para investor.

Hasil penelitian membuktikan bahwa modal kerja tidak berpengaruh terhadap kebijakan dividen. Dalam hal ini besarnya kebutuhan modal kerja tidak relevan dengan kebijakan dividen. Kebijakan dividen hanya dipangaruhi oleh tingkat likuiditas, keuntungan yang dihasilkan oleh perusahaan, proporsi keuntungan yang dialokasikan untuk pembayaran dividen dan kebijakan dividen masing-masing perusahaan. Walaupun dalam penelitian ini menggunakan likuiditas sebagai variabel intervening namun tidak ditemukan adanya pengaruh langsung terhadap kebijakan dividen. Terdapat variabel lain yang mampu memediasi modal kerja terhadap kebijakan dividen namun tidak dianalisis dalam penelitian ini.

\section{PENUTUP}

Hasil penelitian terhadap perusahaan Jakarta Islamic Index (JII) di Bursa Efek Indonesia tahun 2011-2014, menunjukkan bahwa modal kerja tidak berpengaruh signifikan terhadap kebijakan dividen. Dengan kata lain, peningkatan modal kerja tidak dapat mempengaruhi keputusan kebijakan dividen yang diambil oleh perusahaan. Selain itu, modal kerja tidak berpengaruh negatif signifikan terhadap likuiditas. Penelitian ini juga menemukan bahwa likuiditas tidak berpengaruh signifikan terhadap kebijakan dividen sehingga. Selanjutnya, likuiditas tidak mampu memediasi modal kerja terhadap kebijakan dividen, karena modal kerja tidak memengaruhi kebijakan dividen walaupun salah satu faktor berpengaruh terhadap kebijakan dividen adalah likuditas.

Dari hasil penelitian tersebut, diharapkan perusahaan dapat lebih bijak dalam hal penetapan kebijakan dividen sehingga dapat mensejahterakan para pemegang saham. Perusahaan harus mampu mengatur dengan baik kebutuhan modal kerja disamping harus membayar utang jangka pendek jika sudah jatuh tempo.

Penelitian ini mempunyai keterbatasan-keterbatasan yang dapat dijadikan bahan pertimbangan bagi penelitian selanjutnya agar mendapatkan hasil yang lebih baik lagi. Penelitian ini hanya menggunakan faktor-faktor internal untuk mengetahui pengaruh modal kerja (Net Working Capital) terhadap kebijakan dividen (Dividen Payout Ratio) melalui likuiditas (Current Ratio). Penelitian ini hanya menggunakan perusahaan yang terdaftar secara konsisten 
AL-MASHRAFIYAH: Jurnal Ekonomi, Keuangan, dan Perbankan Syariah Volume 2, Nomor 2, Oktober 2018

dalam Jakarta Islamic Index (JII) tahun 2011-2014 sebagai objek penelitian,sehingga belum mencakup keseluruhan jenis perusahaan yang ada. Penelitian ini juga menggunakan periode empat tahun, sehinggga tidak mampu menangkap situasi yang memerlukan periode pengamatan yang lebih lama sehingga hasil penelitian tidak menggambarkan kinerja perusahaan JII secara komprehensif.

\section{DAFTAR PUSTAKA}

Afriani, F., E. Safitri, R. Aprilia. 2013. Pengaruh Profitabilitas, Leverage, Likuiditas dan Pertumbuhan Perusahaan Terhadap Kebijakan Dividen pada Perusahaan Manufaktur Periode 2009-2012. Jurnal STIE MDP Palembang, 10-12.

Bursa Efek Indonesia. 2016. Ringkasan Laporan Kinerja Kenangan Perusabaan Tercatat. www.idx.co.id/id-id/beranda/ringkasankinerjaperusahaantercatat.aspx, (akses tanggal 25 Februari 2017).

Bursa Efek Indonesia. Produk dan Layanan Pasar Syariah dan Jakarta Islamic Index. http://www.idx.co.id/id/beranda/produkdanlayanan/pasarsyariah.aspx, (akses tanggal 29 Februari 2017).

Baramuli, Dedy Natanael. 2016. Pengaruh Likuiditas dan Profitabilitas terhadap Devidend Payout Ratio pada Top Bank di Indonesia (BRI, BANK MANDIRI, BNI, dan BCA). Jurnal Berkala Ilmiah Efisiensi Volume 16 No. 03, h. 356-366.

Baridwan, Zaki.2003. Intermediate Accounting, Edisi keempat. Yogyakarta: BPFE.

Binastuti, Sugiharti. 2012. Faktor Fundamental Terhadap Kebijakan Deviden Studi Kasus pada Perusahaan Manufaktur di BEI. Ejournal.Stienusa.Ac.Id/Index.Php/Ekowir/Article/View/68/68., h. 13-23. ISSN-1411 3880

Bisma, I Dewa Gde. 2009. Hubungan Antara Likuiditas (Current Ratio) Dengan Profitabilitas Earning Per Share) Pada Sektor Industri Kimia Yang Listed Di Bei Tahun 2002-2008, Ganeç Swara.Vol. 3 No.2 September h. 88-95.

Bursa Efek Indonesia. 2016. Informasi bagi Investor: Pengantar Pasar Modal. http://www.idx.co.id/id-

id/beranda/informasi/bagiinvestor/pengantarpasarmodal.aspx, (akses tanggal 03 Februari).

Bursa Efek Indonesia. 2016. Laporan Kenangan dan Tabunan Perusabaan Tercatat di Bursa Efek Indonesia BEI. www.idx.co.idid/beranda/perusahaantercatat/laporankeuangandantahunan.aspx (akses tanggal 23 Februari 2017).

Bursa Efek Indonesia. 2016. Perusabaan Terdaftar di Jakarta Islamic Indeks 2011, 2012, 2013 dan 2014. www.sahamok.com/bei/jii, (akses tanggal 23 Februari 2017).

Bushuru, R.W., K.A. Beswty, P.M.Mukonyi. 2015. The Relations Between Working Capital Management and Dividend Payout Ratio of Firms Listed in Nairobi Securities Exchange. International Journal of Economics, Commerce and Management Vol 3, 1-10. November.

Darmaji, T., H. M. Fakhruddin. 2011. Pasar Modal di Indonesia Edisi 3. Jakarta: Salemba Empat.

Departemen Agama RI. 2009. Al-Qur'an dan Terjemahnya. Semarang: PT. Syigma Examedia Arkanleema.

Fazriani, F., Y.Supriadi. 2011. Pengaruh Modal Kerja terhadap Likuiditas pada PT. Timah Tbk dan PT. Antam Tbk. Jurnal Ilmiah Ranggagading Vol 11 No. 1 , 9-10. April.

Hadiwidjaja, Rini Dwiyani. 2008. Analisis Faktor-faktor yang Mempengaruhi Dividend Payout Ratio Pada Perusahaan Manufaktur di Indonesia. 
Ahmad Rijal, dan Salmah Said. Efektifitas Modal Kerja dan Liquiditas...

https://www.researchgate.net/application.ClientValidation.html?origPath $=\% 2 F$ public ation $\% 2 \mathrm{~F} 42322250$ Analisis Faktor-

faktor yang_Mempengaruhi Dividend Payout Ratio pada Perusahaan Manufaktur di Indonesia, akses tanggal 25 September 2018.

Hansen and Crutchley. 1989. A Test of Agency Theory of Managerial Ownership, Corporate Leverage and Corporate Dividens. Financial Management, Vol. 18. No. 4, 36-46.

Houston, Joel F., Eugene F Brigham. 2011. Dasar-Dasar Manajemen Keuangan, Edisi ke 11, Buku 2. Jakarta: Salemba Empat.

Husnan, Suad. 2004. Dasar-Dasar Teori Portofolio dan Analisis Sekuritas Jilid ke IV. Yogyakarta: UPP AMP YKPN.

Ibadin, Oladipupo, A. O., \& P. Okoguale. 2013. Does Working Capital Management Matter in Dividend Policy Decision. International Journal of Financial Research , 4-5.

Imam, Ghozali. 2005. Aplikasi Analisis Multivariate dengan Program SPSS. Semarang: Universitas Diponegoro.

Jusmaliani, dkk. 2008. Investasi Syari'ah: Implementasi Konsep pada Kenyataan Empirik, Cetakan Pertama. Yogyakarta: Kreasi Kencana.

Kadir, Abdul. 2010. Analisis Faktor-Faktor yang Mempengaruhi Kebijakan Dividen pada Perusahaan Credit Agencies di Bursa Efek Indonesia. Jurnal Manajemen dan Akuntansi, Volume 11, Nomor 1, h. 10-20. Journal.Stiei-KayutangiBjm.Ac.Id/Index.Php/Jv112/Article/.../5/4, akses tanggal 25 September 2018.

Kasmir. 2010. Pengantar Manajemen Keuangan. Jakarta: Kencana.

Keown, Arthur J, dkk. 2005. Manajemen Keuangan Prinsip-Prinsip dan Aplikasi. Jakarta: Pearson Education Inc.

al-Mahili, Imam Jalaluddin., \& Imam Jalaluddin as-Suyuti. 2009. Tafsir Jalalain. Bandung: Sinar Baru Algesindo.

Muhammad Alu Syaikh, A. B. 2009. Tafsir Ibnu Katsir Jilid 1. Jakarta: Pustaka Imam Asy-Syafi'i. Muhammad.2014. Manajemen Keuangan Syariah. Yogyakarta: UPP STIM YKPN.

Muslich, M. 2003. Manajemen Keuangan Modern. Jakarta: Bumi Aksara.

an-Nabhani, Taqiyuddin. 1996 Membangun Sistem Ekonomi Alternatif Perspektif Islam. Surabaya: Risalah Gusti.

Pramana, Gede Rian Aditya; I Made Sukartha. 2015. Analisis Faktor-Faktor yang Memengaruhi Kebijakan Dividen di Bursa Efek Indonesia. E-Jurnal Akuntansi Universitas Udayana 12.2 (2015), ISSN: 2302 - 8556, h. 221-232.

Priyatno, Dwi. 2008. Mandiri Belajar SPSS untuk Analisis Data \& Uji Statistik. Yogyakarta: MediaKom.

Qayyim, Imam Ibnu. 2010. ar-Risâlah at-Tabûkiyyah. Jakarta: Pustaka Azzam.

Qosim, M. Rizal. 2009. Pengamalan Fikih. Yogyakarta: Tiga Serangkai.

Raissa, Febryanno. 2012. Faktor-Faktor yang Mempengaruhi Kebijakan Deviden pada Perusahaan yang Tercatat di PT Bursa Efek Indonesia. journal.wima.ac.id/index.php/jumma/article/download/295/268, akses tanggal 25 September 2018

Riyanto, Bambang. Dasar-Dasar Pembelanjaan Perusabaan Jilid IV. Yogyakarta: BPFE. 2001.

as-Sabitin, Yusuf. 2009. Bisnis Islam \& Kritik Atas Praktik Bisnis Ala Kapitalis. Bogor: Al-Azhar Press.

Saputra, Bambang. 212. Pasar Modal Syariah Indonesia: Alternatif Instrumen Investasi. Makassar: Asosiasi Doktor Ekonomi Indonesia (ADEI).

Sartono, Agus. 2001. Manajemen Keuangan Teori dan Aplikasi. Yogyakarta: BPFE.

ash-Shabuni, Muhammad Ali. 1994. Rawai'ul Bayan: Tafsir ayat-ayat bukum. Semarang: CV. asySyifa.

Shihab, Muhammad Quraish. 2002. Tafsir Al-Mishbah. Jakarta: Lentera Hati. 
AL-MASHRAFIYAH: Jurnal Ekonomi, Keuangan, dan Perbankan Syariah Volume 2, Nomor 2, Oktober 2018

Sholihin, Ahmad. 2010. Buku Pintar Ekonomi Syariah. Jakarta: PT Gramedia.

Sugiyono. 2011. Metode Penelitian Kuantitatif, Kualitatif, dan R\&D. Bandung: Alfabeta.

Sunariyah. 2003. Pengetahuan Pasar Modal. Yogyakarta: UPP AMP YKPN.

Sundaja, R. S., I. Barlian, \& D. P. Sundaja. 2010. Manajemen Kenangan 1 Edisi ke VII Cetakan ke2. Bandung: Literata Lintas Media.

Sunyoto, Danang.2009. Analisis Regresi dan Uji Hipotesis, Cetakan Pertama. Yogyakarta: MedPress.

Suroto. 2015. Faktor - Faktor yang Mempengaruhi Dividend Payout Ratio pada Perusahaan yang terdaftar di Bursa Efek Indonesia Periode 2010 - 2012. Serat Acitya - Jurnal Ilmiah Untag Semarang, h. 18-32.

Syamsuddin, Lukman.2004. Manajemen Kenangan Perusahaan. Jakarta Utara: PT Raja Grafido Persada.

Yulenda, Tria, et.al. 2017. Pengaruh Profitabilitas dan Kebijakan Dividen terhadap Nilai Perusahaan (Studi Kasus pada Perusahaan LQ45 yang terdaftar di Bursa Efek Indonesia Periode 2011-2015). Prosiding Manajemen SPeSIA: Seminar Penelitian Civitas Akademika Unisba, Vol. 3 No. 1, ISSN 2460-6545, h. 27-32.

Yulsiaty, Henny dan Aulia Wayu. 2015. Pengaruh Kebutuhan Modal Kerja Terhadap Likuiditas Perusahaan Asuransi yang Terdaftar di Bursa Efek Indonesia. Jurnal Akuntanika. Jurusan Akuntansi Politeknik Negeri Sriwijaya Palembang. No. 1. Vol. 1. Januari-Jun, h. 11.

Warsono. 2003. Manajemen Keuangan 1 Edisi III. Malang: Bayumedia.

Widnyana, I Wayan. 2015. Pengaruh Kebijakan Dividen dan Profitabilitas terhadap Nilai Perusahaan Manufaktur yang Terdaftar Di Bursa Efek Indonesia Tahun 2010-2013. Jurnal Ilmu Manajemen (JUIMA), Volume 5, Issue 2, h. 24-35.

Wild, J. J., et.al. 2009. Financial Statement Analysis. Jakarta: Salemba Empat. 